\title{
$\mathrm{M}|\mathrm{R}| \mathrm{S}$
}

A Publication of the Materials Research Society

Volume 22, Number 10 ISSN: 0883-7694 CODEN: MRSBEA

LOW-DIELECTRICCONSTANT MATERIALS

19 Low-Dielectric-Constant Materials for ULSI Interlayer-Dielectric Applications

W.W. Lee and P.S. Ho, Guest Editors

28 Vapor Deposition of Low-Dielectric-Constant Polymeric Thin Films T-M. Lu and J.A. Moore

33 Organic and Inorganic Spin-On Polymers for Low-Dielectric-Constant Applications

N.P. Hacker

39 Nanoporous Silica as an Ultralow- $k$ Dielectric

C. Jin, J.D. Luttmer, D.M. Smith, and T.A. Ramos

44 Phase-Separated Inorganic-Organic Hybrids for Microelectronic Applications

R.D. Miller, J.L. Hedrick, D.Y. Yoon, R.F. Cook, and J.P. Hummel

49 Materials Issues and Characterization of Low-k Dielectric Materials

E.T. Ryan, A.J. McKerrow, J. Leu, and P.S. Ho

55 Fluorinated Amorphous Carbon as a Low-DielectricConstant Interlayer Dielectric

K. Endo

61 Integration of Low-k Dielectric Materials Into Sub-0.25- $\mu \mathrm{m}$ Interconnects R.S. List, A. Singh, A. Ralston, and G. Dixit

\section{MRS NEWS}

721997 MRS Fall Meeting Preview

791997 Von Hippel Award Goes to Gabor A. Somorjai for Broad Contributions to Surface Science

80 Merton C. Flemings Selected for 1997 David Turnbull Lectureship for Contributions to Solidification Processing

81 Shuji Nakamura Named 1997 MRS Medalist

81 Plenary Speaker Harry Y. McSween Jr. to Address Materials Findings of the Mars Pathfinder

\section{ABSTRACTS}

95 Abstracts for December 1997 Journal of Materials Research

\section{DEPARTMENTS}

5 Material Matters

The Recent Revolution in High

Performance Computing, H.D. Simon

8 Research/Researchers

14 Washington News

16 Public Affairs Forum

17 Resources

18 Editor's Choice

70 Advertisers in This Issue

93 Career Clips

94 Historical Note

102 Classified

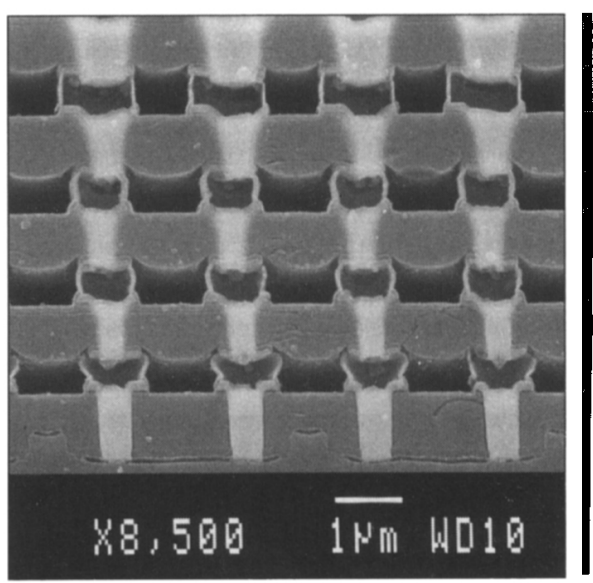

ON THE COVER: Hydrogen silsesquioxane (HSQ) has been successfully integrated into a five-level $W$-plug multilevel interconnect technology. This figure represents a scanningelectron-microscopy cross section showing a pentalevel W-plug and low-dielectric-constant ( $k$ ) HSQ interconnect system. The low-k HSQ appears as the dark regions between the metal lines while the $W$-plugs appear as the bright regions connecting metal lines. Provided by G. Dixit, Texas Instruments, Inc. For more information, see "Integration of Low- $k$ Dielectric Materials into Sub-0.25- $\mu \mathrm{m}$ Interconnects" by R.S. List, A. Singh, A. Ralston, and G. Dixit on p. 61 of this issue. 


\section{About the Materials Research Society}

The Materials Research Society (MRS), a nonprofit scientific association founded in 1973, promotes interdisciplinary goal-oriented basic research on materials of technological importance. Membership in the Society includes over 12,000 scientists, engineers, and research managers from industrial, government, and university research laboratories in the United States and nearly 50 countries.

The Society's interdisciplinary approach differs from that of single-discipline professional societies because it promotes information exchange across the many technical fields touching materials development. MRS sponsors two major international annual meetings encompassing approximately 60 topical symposia, and also sponsors numerous single-topic scientific meetings. The Society recognizes professional and technical excellence and fosters technical interaction in local geographic regions through Sections and University Chapters.

MRS participates in the intemational arena of materials research through the International Union of Materials Research Societies (IUMRS). MRS is a member of the Federation of Materials Societies and is an affiliate of the American Institute of Physics.

MRS publishes symposium proceedings, MRS Bulletin, Journal of Materials Research, and other publications related to current research activities.

MRS Bulletin (ISSN: 0883-7694) is published 12 times a year by the Materials Research Society, 506 Keystone Drive, Warrendale, PA 15086-7573. Application to mail at periodicals rates has been approved at Warrendale, PA and at additional mailing offices. POSTMASTER: Send address changes to MRS Bulletin in care of the Materials Research Society, at the address listed; phone 412779-3003; fax 412-779-8313. Printed in the U.S.A.

Additional copies of articles in MRS Bulletin may be made at $\$ 2.50$ per article. This fee can be paid to the Materials Research Society through the Copyright Clearance Center, Inc, 27 Congress Street, Salem, MA 01970

Membership in MRS is $\$ 75$ annually for regular members, $\$ 25$ for students. Dues include an allocation of $\$ 29$ ( $\$ 17$ for students) to a subscription to MRS Bulletin. Individual member subscriptions are for personal use only. Non-member subscription rates are $\$ 142$ for one calendar year (12 issues) within the U.S.A. and $\$ 195$ elsewhere. Single copies may be purchased for $\$ 16$ each. Send subscription orders to Subscription Department, Materials Research Society, 506 Keystone Drive, Warrendale, PA 15086-7573.

MRS Bulletin is included in Current Contents ${ }^{\circledast / E n}$ gineering, Computing, and Technology; Current Contents $\% / P h y s i c a l$, Chemical, and Earth Sciences, the SciSearch ${ }^{\text {a }}$ online database, Research Alert ${ }^{\text {, Science }}$ Citation Index and the Materials Science Citation Index ${ }^{\text {tx }}$. Back volumes of MRS Bulletin are available in $16 \mathrm{~mm}$ microfilm, $35 \mathrm{~mm}$ microfilm, or $105 \mathrm{~mm}$ microfiche through University Microfilms Inc., 300 North Zeeb Road, Ann Arbor, Michigan 48106.

\section{Materials Research Society 506 Keystone Drive \\ Warrendale, PA 15086-7573 USA}

Tel. 412-779-3003; Fax 412-779-8313 http://www.mrs.org/
Editorial Office • 506 Keystone Drive • Warrendale, PA 15086-7573 USA Tel. 412-779-3004 ext. 522; fax 412-779-8313; http://www.mrs.org/
Editor

E.L. Fleischer

J. Meiksin

Assistant Editor

L.R. Gallagher

Art Director

E. Stiller

Design/Production

T. Aiello and S. Franklin

Editorial Assistants

J. Dininny and

M. Wilmoth
Managing Editor

\section{Advertising}

M.E. Kaufold

Circulation

S. Krasa

Guest Editors

W.W. Lee and P.S. Ho

Special Contributors

S. Beckerman, E.N. Kaufmann,

J.M. Phillips, D. Sankey,

H.D. Simon, and L.A. Snyder

Special Consultant

M. Goodway
Associate Editor-Europe

I.W. Boyd, University College London Dept. of Electronic and

Electrical Engineering

Torrington Place

London WCI E7 JE, U.K

Tel. 44-171-380-7300 or 7302

\section{Book Review Board}

M.A. Nastasi (Chair), J.C. Bravman

R.W. Cahn, M.L. Green, and

E.J. Kramer

MRS Office of Public Affairs

601 13th Street, NW, Suite 1000 South Washington, DC 20005-3807

Tel. 202-661-2285, Fax 202-661-2299

\section{EDITORIAL BOARD}

M.A. Nastasi, Chair

Los Alamos National Laboratory

Los Alamos, NM

W.L. Brown

Bell Laboratories, Lucent Technologies

Murray Hill, $\mathrm{N}_{\mathrm{v}}$

R.W. Cahn (1997 Visiting Scientist)

Cambridge University

Cambridge, UK

D.J. Eaglesham

Bell Laboratories, Lucent Technologies

Murray Hill, NJ

E.J. Kramer

University of California-Santa Barbara

Santa Barbara, CA

G.G. Long

National Institute of Standards and Technology,

Gaithersburg, MD

S.C. Moss

Aerospace Corporation

Los Angeles, CA

W.D. Nix

Stanford University

Stanford, CA

\section{VOLUME ORGANIZERS}

0 . Auciello

Argonne National Laboratory

R.J. Composto

University of Pennsylvania

Philadelphia, PA

\section{S.J. Pearton}

University of Florida

Gainesville, FL

\section{S.T. Picraux}

Sandia National Laboratories

Y. Shiohara

ISTEC

Tokyo, Japan

C.C. Tsai

Applied Komatsu Technology

Santa Clara, CA

Argonne, IL
P.M. Fauchet

University of Rochester

Rochester, NY
Albuquerque, NM

\section{COMMITTEE}

\section{M.A. Nastasi, Chair}

Los Alamos National Laboratory

Los Alamos, NM

F.W. Clinard (1996 Visiting Scientist) Los Alamos National Laboratory

Los Alamos, NM

R.C. Ewing

University of Michigan

Ann Arbor, MI
R.L. Fleischer (1995 Visiting Scientist)

Union College

Schenectady, NY

A.J. Hurd

Sandia National Laboratories

Albuquerque, NM

M. Libera

Stevens Institute of Technology

Hoboken, NJ

\begin{tabular}{lc}
\hline & 1997 MRS EXECUTVE COMMITEE \\
\hline President & Treasurer \\
R. Hull & A. Hurd \\
University of Virginia & Sandia National Laboratories \\
Vice President and President-Elect & Immediate Past President \\
R.J. Nemanich & C.V. Thompson \\
North Carolina State University & Massachusetts Institute of \\
Secretary & Technology \\
K.S. Jones & \\
University of Florida &
\end{tabular}

\section{Councillors}

R. Gibala

University of Michigan

A.l. Tauó

Ford Research Laboratory

Executive Direclor

Materials Research Society

John B. Ballance
C.W. White

Oak Ridge, TN

\section{INTERNATIONAL UNION OF MATERIALS RESEARCH SOCIETIES}

President

R.C. Ewing

University of Michigan

Ann Arbor, MI, USA

Vice President
H-D. Li
Tsinghua University
Beijing, China

H-D. Li

Beijing, China
Secretary

C. Li

Aviation Industries of China

Beijing, China

Treasurer
G.M. Crean
University College
Cork, Ireland

Immediate Past President

M. Doyama

Nishi-Tokyo University

Tokyo, Japan
General Secretary

R.P.H. Chang

Northwestern University

Evanston, Illinois, USA

IUMRS ADHERING BODIES

Australian Materials Research Society (A-MRS)

J.S. Williams, Australian National University

Chinese Materials Research Society (C-MRS)

$\mathrm{H}-\mathrm{D}$. Li, Tsinghua University

European Materials Research Society (E-MRS)

G.M. Crean, University College

Materials Research Society (MRS)
Materials Research Society of India (MRS-I)

S.K. Joshi, JNCASR, New Delhi

Materials Research Society of Japan (MRS-J)

R-I. Yamamoto, University of Tokyo

Materials Research Society of Korea (MRS-Korea)

S-J. Park, Seoul National University
Materials Research Society of Russia (MRS-Russia)

I.V. Gorynin, Prometey Institute

Materials Research Society of Taiwan (MRS-T)

L.J. Chen, National Tsing Hua University

Mexican Materials Research Society (Mexican-MRS)

L.M. Gomez, Instituto de Fisica-Cuernavaca, UNAM 